\title{
Effects of aluminum, nitrate and ammonium on the growth, potassium content and composition of amino acids in Stylosanthes
}

\author{
Efectos de aluminio, nitrato y amonio en el crecimiento, contenido \\ de potasio y composición de aminoácidos en Stylosanthes \\ José Augusto Teixeira do Amaral ${ }^{1 *}$, Alemar Braga Rena ${ }^{2}$, \\ Antonio Teixeira Cordeiro ${ }^{2}$, Edilson Romais Schmildt ${ }^{3}$
}

\begin{abstract}
The effects of the aluminum, nitrate and ammonium interaction, in nutritive solution, were studied under controlled conditions. An analysis was performed on the growth, potassium concentrations, and percentage composition of $\mathrm{N}$ of the amino acids in Stylosanthes guianensis and S. macrocephala, sensitive and resistant, respectively, both to aluminum and to ammonium. The ammonium nutrition reduced the growth of the $S$. guianensis drastically. The ammonium toxicity, verified only in the $S$. guianensis, was associated to the stimulation of the metabolic routes syntheses of proline and arginine, starting from the glutamic acid, to the detriment of the glutamine synthesis. The aluminum partially alleviated the ammonium toxicity in the S. guianensis, increasing the asparagine retention and reducing the arginine composition in the root system. In the presence of the nitric source, the aluminum increased the potassium concentrations only in the S. macrocephala. In the presence of nitric source, the interconversion of $\mathrm{N}$-aminic was influenced by aluminum in both species, however the percentage composition of $\mathrm{N}$-amino acids was more modified in the $S$. macrocephala.
\end{abstract}

Key words: aluminum toxicity, ammonium toxicity, aluminum tolerance.

\section{RESUMEN}

Se estudiaron en condiciones controladas los efectos de la interacción entre el aluminio, nitrato y amonio, en solución nutritiva. Se realizó un análisis sobre el crecimiento, las concentraciones de potasio y la composición porcentual de $N$ de los aminoácidos en Stylosanthes guianensis y S. macrocephala, sensibles y resistentes, respectivamente, tanto al aluminio y al amonio. El amonio redujo el crecimiento del S. guianensis drásticamente. La toxicidad de amonio, comprobada solo en el S. guianensis, estaba asociada con la estimulación de la síntesis de las rutas metabólicas de la prolina y arginina, a partir del ácido glutámico, en detrimento de la síntesis de glutamina. El aluminio alivia parcialmente la toxicidad de amonio en el $\mathrm{S}$. guianensis, concomitante al aumento en la retención de asparagina y reducción en la composición de arginina en el sistema de raíces. En presencia de la fuente nítrica, el aluminio aumentó las concentraciones de potasio solo en el S. macrocephala. En presencia de la fuente nítrica, la interconversión de $N$-amínico fue influenciada por el aluminio en ambas especies; sin embargo, la composición porcentual de $\mathrm{N}$-aminoácidos se modificó más en el S. macrocephala.

Palabras clave: toxicidad de aluminio, toxicidad de amonio, tolerancia al aluminio.

\section{Introduction}

Aluminum is the third most abundant chemical element in the earth's crust, after oxygen and silicon. In strongly acidic soils aluminum exists in toxic ionic forms, and many mechanisms can be invoked to explain the differential tolerance of plants to this element (Foy et al., 1978; Delhaize and Ryan, 1995; Kochian, 1995; Jones, 1998; Samac and Tesfaye, 2003; Kochian et al., 2004).

One toxic effect of the aluminum in plants is the interference in absorption of minerals,

\footnotetext{
Departamento de Produção Vegetal, Universidade Federal do Espírito Santo - UFES, CEP: 29500-000, Alegre-ES.

Departamento de Biologia Vegetal, Universidade Federal de Viçosa - UFV.

Centro Universitário do Norte do Espírito Santo, UFES.

Corresponding author: jata@cca.ufes.br
} 
especially phosphorus (Foy et al., 1978; Machado et al., 1992; Marschner, 1995). The studies of the absorption kinetics in Stylosanthes, Machado et al. (1992) concluded that the reduction in the absorption rate of phosphorus by aluminum cannot elucidate the physiological mechanism that grants some plants differential tolerance to this element, but a generalized action of aluminum in plasmalemma entail changes in phosphate transport system.

The aluminum can reduce the absorption of $\mathrm{K}$ by competitive inhibition (Malavolta et al., 1997). It has been found that the potassium deficiency, induced by aluminum, affects nitrogen metabolism by stimulating the accumulation of putrescine (Basso et al., 2007), whose diamine interacts with phospholipids, and reduces the fluidity of the plasmatic membrane (Roberts et al., 1983).

Although extensive efforts have been directed towards unraveling the harmful effects of aluminum, the causes of metabolic toxicity of this element remain obscure. It is possible that physiological mechanism of aluminum tolerance is associated with the assimilation of $\mathrm{N}$-aminic, since species adapted to acidic soils can tolerate levels of ammonium and aluminum, which are normally toxic to nonadapted species (Foy et al., 1978). The sensitivity to ammonium is linked to the accumulation of this ion in the shoot, while tolerant plants would be more able to retain and assimilate the ammonium in the root system (Amaral et al., 2000).

In Stylosanthes aluminum also increases the absorption of nitrogen in tolerant species (Cordeiro, 1981), leading to an increases of nitrate, free amino acids (Amaral et al., 2000) and proteins contents in tissues (Mosquim, 1978), possibly due to a stimulus in nitrate reductase and glutamine synthetase activities (Gonçalves, 1983). This increase in nitrogen metabolism in tolerant species subjected to aluminum is related to the synthesis of specific proteins (Basu et al., 1999; Iuchi et al., 2007; Kobayashi et al., 2007) that grants differential tolerance of plants to aluminum (Klimashevskii et al., 1970).

This work aimed to study the aluminum, nitrate and ammonium interaction on growth, potassium content and percentage composition of $\mathrm{N}$-aminic in Stylosanthes macrocephala and S. guianensis, considered tolerant and susceptible, respectively, both to aluminum and to ammonium.

\section{Materials and Methods}

The experiment was conducted under controlled conditions in a growth chamber with a temperature of $28 \pm 2^{\circ} \mathrm{C}$, relative humidity around $55 \%$, and photoperiod of 12 hours and illuminance of 15 klux. Two Stylosanthes species, the $S$. guianensis (Aubl.) Sw and the S. macrocephala M. B. Ferr. et Souza Costa, considered susceptible and tolerant, respectively, both to aluminum and to ammonium, were used in the studies.

Seeds were scarified with sanding wooden surface sterilized with sodium hypochlorite at $0.5 \%$ for 10 minutes, washed several times with distilled water and germinated in Petri dishes containing a solution of calcium chloride $(0.053 \mathrm{mM})$. After 36 hours, the germinated seeds were transferred to sterile plastic boxes with vermiculite, moistened by capillarity with a solution of calcium chloride $(0.53 \mathrm{mM})$ and micronutrients at the following concentrations in $\mathrm{mg} \mathrm{g}^{-1}: \mathrm{Fe}=2.2 ; \mathrm{B}=0.5$; $\mathrm{Mn}=0.38 ; \mathrm{Zn}=0.05 ; \mathrm{Cu}=0.02 ; \mathrm{Mo}=0.02$ and $\mathrm{Cl}=22.7$.

After 36 hours the plants were selected, which were transferred to plastic flasks, coated externally ink aluminum, containing $1.6 \mathrm{~L}$ of nutrient solution for growth, with the following composition, in $\mathrm{mg}$ $\mathrm{g}^{-1}: \mathrm{N}=32 ; \mathrm{P}=0.4 ; \mathrm{K}=70 ; \mathrm{CA}=40 ; \mathrm{Mg}=12$; $\mathrm{S}=54.4$ and micronutrients as described above. Nitrogen was supplied in the ratio of $7: 1\left(\mathrm{~N}-\mathrm{NO}_{3}^{-}\right.$: $\mathrm{N}-\mathrm{NH}_{4}^{+}$). Plants were grown under these conditions for 10 days.

The first exchange of nutrient solutions was performed four days after transfer the plants for plastic bottles of $1.6 \mathrm{~L}$ and the further exchange of nutrient solutions were made every two days. Twenty-four hours before subjecting the plants to treatment, the nutrient solution was replaced by another, which contained only calcium and micronutrients, in the concentrations described above. After this time, they were removed three pots of each species, each containing 20 plants, previously established for the determination of dry biomass at the start of the treatments.

Treatments were initiated by modification of nutrient solution for growth, replacing the formulation of nitrogen supplied at that stage only by the addition of nitrate or ammonium, in the presence or absence of aluminum. In order to obtain $100 \%$ nitrogen in nitrate form or $100 \%$ nitrogen in ammoniacal 
form, the S levels were 44.2 and 115.8, the $\mathrm{Na}$ levels were 21.3 and 18.4 and the $\mathrm{Cl}$ levels were 22.7 and $21.3 \mathrm{mg} \mathrm{g}^{-1}$, respectively. The exchanges of nutrient solutions, in this stage, were performed daily. At all stages of the experiment the $\mathrm{pH}$ of the solutions was adjusted daily to $4.00 \pm 0.02$ with $\mathrm{H}_{2} \mathrm{SO}_{4}(0.1 \mathrm{~N})$ or $\mathrm{NaOH}(0.1 \mathrm{~N})$.

The experimental design was completely randomized in a factorial $2 \times 2 \times 2$, being two species, two aluminum levels $\left(0\right.$ and $\left.9 \mathrm{mg} \mathrm{g}^{-1}\right)$ provided as $\mathrm{Al}_{2}\left(\mathrm{SO}_{4}\right)_{3} \cdot 18 \mathrm{H}_{2} \mathrm{O}$ and two nitrogen sources (nitric and ammonium), with three replications. Each replication consisted of 20 plants. Twelve days after the start of treatment was made collection of plants at random in each repetition, severing them at the time of the girth and separating them into shoot and root system. The roots were rinsed with distilled water and wiped with absorbent paper.

Half the plants from each replication, of each treatment, were oven-dried at $75^{\circ} \mathrm{C}$ until constant weight. Then the relative growth rates (RGT) were calculated (Amaral et al., 2009). Subsequently, these samples were pulverized in Willey mill with 40 mesh sieve, and stored in glass vials. In the extract, obtained by nitropercloric digestion, were measured the levels of K, by flame photometry.

The other ten plants from each replication of each treatment, immediately after collection, were quickly weighed to obtain the biomass of shoots and roots. After that, the shoots and roots were immediately fragmented separately using scissors, and immersed in boiling $80 \%$ ethanol, and stored in a freezer at $-10^{\circ} \mathrm{C}$, for subsequent procedures.

The method described by Amaral et al. (2000) was performed for the extraction and preparation of extracts used in the quantification of soluble amino acids of the samples was used. The amino acids were assayed from samples mixed by combining the three replicates of each treatment, so as to form a composite sample. The amino acid composition determinations were carried out by ion exchange chromatography (Spackman et al., 1958), using an amino acid automatic analyzer Beckman model 121. To this end, were used as a standard solution a synthetic mixture containing $0.5 \mu$ moles $\mathrm{ml}^{-1}$ of 17 amino acids normally found in protein hydrolysates, to which was added norleucine, at the same concentration as the internal standard.

The contents of the amides glutamine and asparagine were determined by difference between the concentration of glutamic acid and aspartic acid found in the hydrolyzed and non-hydrolyzed fractions, respectively. The results of each treatment were expressed as a percentage by dividing the $\mathrm{N}$-amino acids content per total $\mathrm{N}$-amino acids and multiplying this quotient by 100 .

\section{Results and Discussion}

In the absence of the aluminum in the nutrient solution, the ammonium nutrition compared to the nitric, although has not influenced the growth of $S$. macrocephala, drastically reduced the relative growth rates of $S$. guianensis, especially in root system (Table 1). These decreases in growth rates were of $41 \%$ and $64 \%$ approximately to the shoots and root system, respectively. Differences in resistance to ammonium nutrition were noted by Maynard and Barker (1969) and by Amaral et al. (2000), which were associated with the accumulation of ammonium in the shoots.

Table 1. Relative growth rates (RGR) of shoots and roots of Stylosanthes guianensis and S. macrocephala growing in nutritive solution containing two nitrogen sources $\left(\mathrm{N}-\mathrm{NO}_{3}^{-}\right.$and $\left.\mathrm{N}-\mathrm{NH}_{4}^{+}\right)$and two aluminum levels $\left(0\right.$ and $\left.9 \mathrm{mg} \mathrm{g}^{-1}\right)$

\begin{tabular}{|c|c|c|c|c|c|c|c|c|}
\hline \multirow{5}{*}{ Part of plant } & \multicolumn{4}{|c|}{ S. guianensis } & \multicolumn{4}{|c|}{ S. macrocephala } \\
\hline & \multicolumn{2}{|c|}{$\mathrm{N}-\mathrm{NO}_{3}^{-}$} & \multicolumn{2}{|c|}{$\mathrm{N}-N H_{4}^{+}$} & \multicolumn{2}{|c|}{$\mathrm{N}-\mathrm{NO}_{3}^{-}$} & \multicolumn{2}{|c|}{$\mathrm{N}-N H_{4}^{+}$} \\
\hline & \multicolumn{8}{|c|}{ Aluminum levels $\left(\mu \mathrm{g} \mathrm{g}^{-1}\right)$} \\
\hline & 0 & 9 & 0 & 9 & 0 & 9 & 0 & 9 \\
\hline & \multicolumn{8}{|c|}{ RGR (mg mg ${ }^{-1}$ day $\left.^{-1}\right)$} \\
\hline Shoots & $0,111 \mathrm{ab}$ & $0,105 \mathrm{ab}$ & $0,066 \mathrm{c}$ & $0,083 \mathrm{bc}$ & $0,099 \mathrm{a}$ & $0,093 \mathrm{a}$ & $0,111 \mathrm{a}$ & $0,100 \mathrm{a}$ \\
\hline Roots & $0,132 \mathrm{a}$ & $0,128 \mathrm{a}$ & $0,048 \mathrm{~b}$ & $0,079 \mathrm{~b}$ & $0,095 \mathrm{a}$ & $0,106 \mathrm{a}$ & $0,107 \mathrm{a}$ & $0,112 \mathrm{a}$ \\
\hline
\end{tabular}

Means followed by the same letters horizontally for each species do not differ by Tukey test at 5\% probability. 
The introduction of aluminum in nutrient solution equaled the effects of two sources of nitrogen in relation to shoots growth (Table 1). Similar results were found by Kotze et al. (1977) in peach and Cordeiro (1981) in S. guianensis. It has been briefly described that the addition of low levels of aluminum stimulates the plants growth (Marschner, 1995; Taiz and Zeiger, 2009). However, very little is known about this protective effect of aluminum in susceptible species subjected to ammonium nutrition.

A beneficial effect of aluminum, at low $\mathrm{pH}$ levels, was noticed by Fawzy et al. (1954) in isolated barley roots, suggesting that the protective effect of polyvalent cations would be due, at least in part, from an interaction of cations and $\mathrm{H}^{+}$ions. Whereas the increase in hydrogen ion concentration of the absorption solution, when all the nitrogen source was supplied by ammonia source, was not altered by aluminum (Cordeiro, 1981), it is possible that the beneficial action of aluminum in S. guianensis supplied with ammonium, is related to the increased concentration of hydrogen ions within the cell cytoplasm.

Some researchers (Kotze et al., 1977; Cordeiro, 1981; Amaral et al., 2000) have found that the toxic effects of aluminum are manifested only when nitrogen is supplied by nitric source. Cordeiro (1981) demonstrated that the addition of $9 \mathrm{mg} \mathrm{g}^{-1}$ of aluminum to the culture medium for 27 days, when nitrate was the nitrogen source, reduced the growth of susceptible species principally. However, the results of this study indicate that aluminum is not statistically influenced the growth rates of the two species when supplied with nitrate, although there were trends of reduction of the relative growth rate in S. guianensis under these conditions (Table 1). Certainly, the short time of the experimental phase of this study, which lasted for 12 days, would not be enough for the aluminum markedly alter the relative growth rates of the susceptible species in the presence of nitrate source.

In the presence of nitric source, aluminum increased potassium concentrations in S. macrocephala, which did not occur in S. guianensis. When the nitrogen source was supplied by ammoniacal source, aluminum does not affect the absorption of potassium in both species (Table 2).

The increase in the potassium content of S. macrocephala supplied with nitrate, in the presence of aluminum, must be indirectly associated with stimulation of aluminum with activities of nitrate reductase and glutamine synthetase (Gonçalves, 1983), increases in nitrate absorption (Cordeiro, 1981; Gonçalves, 1983) and increases in nitrate content (Amaral et al., 2000) in S. macrocephala. It is known that the nitrate assimilation can influence the balance cation-anion, leading to continuous electrochemical changes that can be transferred to raise the $\mathrm{pH}$ of the medium and to form anions of organic acids.

Several species secreted organic acids in response to toxic levels of aluminum. There were observed excretion of malate in wheat (Ryan et al., 1997) and Arabidopsis (Kobayashi et al., 2007), of citrate in maize (Pellet et al., 1995), bean (Myasaka et al., 1991; Shen et al., 2004), soybean (Yang et al., 2001), Cassia tora (Ma et al., 1997), rye (Li et al., 2000) and Vigna umbellata (Yang et al., 2006). It is known that an accumulation of these organic acids is accompanied by increases in absorption of cations to maintain cells electroneutrality (Kirkby and Knight, 1977). Thus, an increase in nitrate assimilation, by the

Table 2. Potassium content in dry biomass of shoots and roots of Stylosanthes guianensis and S. macrocephala growing in nutritive solution containing two nitrogen sources $\left(\mathrm{N}-\mathrm{NO}_{3}^{-}\right.$and $\left.\mathrm{N}-\mathrm{NH}_{4}^{+}\right)$and two aluminum levels $\left(0\right.$ and $\left.9 \mathrm{mg} \mathrm{g}^{-1}\right)$

\begin{tabular}{|c|c|c|c|c|c|c|c|c|}
\hline \multirow{5}{*}{ Part of plant } & \multicolumn{4}{|c|}{ S. guianensis } & \multicolumn{4}{|c|}{ S. macrocephala } \\
\hline & \multicolumn{2}{|c|}{$\mathrm{N}-\mathrm{NO}_{3}^{-}$} & \multicolumn{2}{|c|}{$\mathrm{N}-\mathrm{NH}_{4}^{+}$} & \multicolumn{2}{|c|}{$\mathrm{N}-\mathrm{NO}_{3}^{-}$} & \multicolumn{2}{|c|}{$\mathrm{N}-N H_{4}^{+}$} \\
\hline & \multicolumn{8}{|c|}{ Aluminum levels $\left(\mu \mathrm{g} \mathrm{g}^{-1}\right)$} \\
\hline & 0 & 9 & 0 & 9 & 0 & 9 & 0 & 9 \\
\hline & \multicolumn{8}{|c|}{ Potassium content $\left(\mathrm{mg} \mathrm{g}^{-1}\right)$} \\
\hline Shoots & $55,2 \mathrm{a}$ & $58,4 \mathrm{a}$ & $59,4 \mathrm{a}$ & $62,0 \mathrm{a}$ & $28,6 \mathrm{~b}$ & $37,3 \mathrm{a}$ & $33,1 \mathrm{ab}$ & $36,5 \mathrm{a}$ \\
\hline Roots & $87,9 \mathrm{a}$ & $80,6 \mathrm{a}$ & $81,9 \mathrm{a}$ & $94,3 \mathrm{a}$ & $49,9 \mathrm{c}$ & $79,0 \mathrm{a}$ & $59,9 \mathrm{bc}$ & $72,9 \mathrm{ab}$ \\
\hline
\end{tabular}


action of aluminum, in the S. macrocephala, should increase the concentration of $\mathrm{OH}^{-}$ions in the tissues, which would be neutralized by the dissociation of organic acids. Therefore, a potassium absorption increase in the tolerant species supplied with nitrate (Table 2) may occur to maintain electrochemical balance within of the cell.

The percentage composition of $\mathrm{N}$-amino acids may indicate probable deviation of the metabolic pathways of these compounds. It is observed that, in the absence of aluminum in the nutrient solution, the ammonia source, compared to nitric, decreased the relative contribution of aspartic acid, glutamic acid, alanine and asparagine in the shoots of the two species (Table 3 ).

These decreases in the shoots occurred simultaneously with the appearance of symptoms of ammonium toxicity only in S. guianensis (Amaral et al., 2000) and with increases in the relative share of arginine and proline in S. guianensis and arginine, glutamine and serine in S. macrocephala (Table 3). At root, in the absence of aluminum in the nutrient solution, the ammonia source, compared to nitric, increased the relative contribution of arginine in

Table 3. Percentage composition of $\mathrm{N}$-amino acid in shoots of Stylosanthes guianensis and $S$. macrocephala growing in nutritive solution containing two nitrogen sources $\left(\mathrm{N}-\mathrm{NO}_{3}^{-}\right.$and $\left.\mathrm{N}-\mathrm{NH}_{4}^{+}\right)$and two aluminum levels $\left(0\right.$ and $\left.9 \mathrm{mg} \mathrm{g}^{-1}\right)$

\begin{tabular}{|c|c|c|c|c|c|c|c|c|}
\hline \multirow{5}{*}{ Amino acids } & \multicolumn{4}{|c|}{ S. guianensis } & \multicolumn{4}{|c|}{ S. macrocephala } \\
\hline & \multicolumn{2}{|c|}{$\mathrm{N}-\mathrm{NO}_{3}^{-}$} & \multicolumn{2}{|c|}{$\mathrm{N}-\mathrm{NH}_{4}^{+}$} & \multicolumn{2}{|c|}{$\mathrm{N}-\mathrm{NO}_{3}^{-}$} & \multicolumn{2}{|c|}{$\mathrm{N}-\mathrm{NH}_{4}^{+}$} \\
\hline & \multicolumn{8}{|c|}{ Aluminum levels $\left(\mu \mathrm{g} \mathrm{g}^{-1}\right)$} \\
\hline & 0 & 9 & 0 & 9 & 0 & 9 & 0 & 9 \\
\hline & \multicolumn{8}{|c|}{$\mathrm{N}$-amino acids $(\%)$} \\
\hline Aspartic acid & 10,1 & 7,7 & 0,8 & 1,0 & 12,5 & 8,6 & 6,0 & 4,9 \\
\hline Glutamic acid & 21,7 & 16,7 & 1,2 & 1,7 & 23,7 & 14,6 & 8,4 & 7,4 \\
\hline Alanine & 5,2 & 3,7 & 1,2 & 2,1 & 6,3 & 2,3 & 3,3 & 2,6 \\
\hline Arginine & 5,9 & 8,4 & 35,5 & 34,8 & 1,7 & 13,6 & 13,5 & 18,4 \\
\hline Asparagine & 38,0 & 37,8 & 22,3 & 15,4 & 40,7 & 43,8 & 31,8 & 37,7 \\
\hline Glutamine & 11,0 & 13,4 & 11,8 & 12,9 & 7,2 & 9,3 & 22,1 & 16,8 \\
\hline Proline & 1,7 & 3,9 & 15,6 & 16,2 & 0,6 & 1,5 & 1,4 & 1,3 \\
\hline Serine & 3,5 & 4,8 & 3,2 & 6,3 & 5,3 & 3,7 & 10,2 & 8,6 \\
\hline Others & 2,9 & 3,6 & 8,4 & 9,6 & 2,0 & 2,6 & 3,3 & 2,3 \\
\hline
\end{tabular}

Table 4. Percentage composition of $\mathrm{N}$-amino acids in roots of Stylosanthes guianensis and $S$. macrocephala growing in nutritive solution containing two nitrogen sources $\left(\mathrm{N}-\mathrm{NO}_{3}^{-}\right.$and $\left.\mathrm{N}-\mathrm{NH}_{4}^{+}\right)$and two aluminum levels $\left(0\right.$ and $\left.9 \mathrm{mg} \mathrm{g}^{-1}\right)$

\begin{tabular}{|c|c|c|c|c|c|c|c|c|}
\hline \multirow{5}{*}{ Amino acids } & \multicolumn{4}{|c|}{ S. guianensis } & \multicolumn{4}{|c|}{ S. macrocephala } \\
\hline & \multicolumn{2}{|c|}{$\mathrm{N}-\mathrm{NO}_{3}^{-}$} & \multicolumn{2}{|c|}{$\mathrm{N}-\mathrm{NH}_{4}^{+}$} & \multicolumn{2}{|c|}{$\mathrm{N}-\mathrm{NO}_{3}^{-}$} & \multicolumn{2}{|c|}{$\mathrm{N}-\mathrm{NH}_{4}^{+}$} \\
\hline & \multicolumn{8}{|c|}{ Aluminum levels $\left(\mu \mathrm{g} \mathrm{g}^{-1}\right)$} \\
\hline & 0 & 9 & 0 & 9 & 0 & 9 & 0 & 9 \\
\hline & \multicolumn{8}{|c|}{$\mathrm{N}$-amino acids $(\%)$} \\
\hline Aspartic acid & 6,2 & 5,1 & 1,1 & 1,4 & 2,9 & 2,4 & 0,9 & 1,3 \\
\hline Glutamic acid & 6,7 & 5,3 & 1,2 & 1,2 & 4,5 & 3,7 & 1,7 & 2,1 \\
\hline Alanine & 6,5 & 3,9 & 0,2 & 0,3 & 8,1 & 1,8 & 1,2 & 1,6 \\
\hline Arginine & 6,7 & 8,1 & 32,8 & 16,6 & 3,5 & 2,8 & 4,1 & 4,3 \\
\hline Asparagine & 58,4 & 63,8 & 53,3 & 71,8 & 66,5 & 79,9 & 51,9 & 59,4 \\
\hline Glutamine & 5,2 & 4,9 & 3,1 & 3,6 & 6,0 & 5,1 & 37,6 & 28,2 \\
\hline Proline & 0,4 & - & - & - & 1,1 & 0,4 & 0,3 & 0,4 \\
\hline Serine & 4,8 & 3,4 & 1,1 & 0,8 & 3,8 & 1,8 & 1,0 & 1,1 \\
\hline Others & 5,1 & 5,5 & 7,2 & 4,3 & 3,6 & 2,1 & 1,3 & 1,6 \\
\hline
\end{tabular}


S. guianensis and of glutamine in S. macrocephala (Table 4).

When ammonium was the nitrogen source, the participation of glutamine was higher in S. macrocephala. Moreover, the relative contribution of arginine in shoots (Table 3) and in roots (Table 4) was much higher in S. guianensis. In S. macrocephala, unlike $S$. guianensis, the relative share of proline in shoots and roots was little changed by ammonium nutrition.

The nitrogen assimilation and synthesis of amino acids and its regulation involves the participation of a complex series of biochemical pathways (Bryan, 1976; Atkins and Beevers, 1990; Lea and Miflin, 2003; Taiz and Zeiger, 2009). Thus, in S. guianensis supplied with ammonium (Tables 3 and 4) higher stimulus of metabolic pathways must have occurred, which leads to the synthesis of proline and arginine starting from the glutamic acid, instead of glutamine synthesis.

In regard to the root of $S$. macrocephala, the ammonia source, compared to nitrate did not influence the relative participation of arginine and glutamine increased (Table 4). In contrast, in S. guianensis the relative contribution of glutamine was basically not changed and arginine increased.

Therefore, it is possible that $S$. macrocephala has developed a more refined mechanism to detoxify itself from the harmful effects of ammonium nutrition, than the $S$. guianensis. This mechanism of resistance appears to be associated with the retention of ammonium in the root system, since the tolerant species, $S$. macrocephala, ammonia accumulates in the root system, whereas the susceptible species, $S$. guianensis, ammonia accumulates in the shoot (Amaral et al., 2000). Consequently, S. macrocephala would have greater ability to retain and assimilate the ammonium ion in the root system, preventing the accumulation of this cation in the shoot (Amaral et al., 2000), where it exerts harmful effects at relatively low concentrations (Hageman and Below, 1990).

According Taiz and Zeiger (2009) the toxicity of ammonium depolarizes the membrane system can dissipate the $\mathrm{pH}$ gradient across the plasmalemma, the vacuoles membranes, and the membranes of mitochondria and chloroplasts. It should be noted, though, that incorporates ammonium tolerant species mainly glutamine, preventing the accumulation of arginine from glutamic acid. Arginine in contrast can be degraded by the action of arginase, yielding ornithine and urea, or it can be catabolized by another metabolic pathway involving the action of enzymes arginine decarboxylase, and agmatine iminohidrolase $\mathrm{N}$-carbomoilputrescina aminohidrolase to yield putrescine, ammonia and $\mathrm{CO}_{2 \text { (Kumar and }} \mathrm{Abrol}, 1990$ ).

It appears that the decreases in the relative contribution of aspartic acid on S. guianensis, supplied with ammonium, may explain the increases in the relative share of arginine, since this amino acid condenses with citrulline to form arginosuccinate, the immediate precursor of arginine (Bryan, 1976). This would explain also the largest decrease in relative contribution of asparagine, which occurred in the shoots of $S$. guianensis supplied with ammonium (Table 3), since the increment in using aspartic acid for the synthesis of arginine limit the synthesis of amide. However, the reduction in the relative alanine in both species supplied with ammonium (Tables 3 and 4) must be associated in some way, a partial inhibition of alanine aminotransferase.

Aluminum partially alleviated the symptoms of ammonium toxicity in $S$. guianensis. These beneficial effects of aluminum in solution cultivation of $S$. guianensis supplied with ammonium were accompanied by decreases in the relative share of asparagine in shoots (Table 3) and arginine and other amino acids (histidine, isoleucine, leucine, valine and lysine) in the roots of this species (Table 4). Concomitantly, there was an increase in the relative contribution of asparagine in roots and serine in shoots.

These variations in relative composition of $\mathrm{N}$-amino acids may at least partly explain the beneficial effect of aluminum on $S$. guianensis during ammonium nutrition. This is a result due to the aluminum improving the retention of asparagine in the root system of $S$. guianensis (Tables 3 and 4) and caused a decrease in levels of ammonia-N in shoots of S. guianensis (Amaral et al., 2000).

In $S$. guianensis supplied with nitrate, in the presence of aluminum, the relative share of alanine, glutamic acid and aspartic acid tended to decrease in the shoot (Table 3). Simultaneously there was elevated relative contribution of arginine, serine and proline, suggesting deviation of amino acid metabolic pathway, from glutamic acid.

In $S$. macrocephala supplied with nitrate, aluminum caused a decrease in the relative contribution of alanine, glutamic acid, aspartic acid and serine in shoots, followed by increases in the relative share of arginine and proline. Concomitantly, there were symptoms of aluminum toxicity only in S. guianensis supplied with nitrate, 
as described by Amaral et al. (2000). In tolerant species $S$. macrocephala, supplied with nitrate, the percentage composition of $\mathrm{N}$-amino acids were altered by more aluminum than in susceptible species, S. guianensis (Tables 3 and 4), similar to the results achieved by Klimashevskii et al. (1970) on pea plants susceptible and resistant to aluminum.

\section{Conclusions}

The ammonia source drastically reduces the growth of susceptible species, $S$. guianensis.

The ammonium toxicity occurs only in the S. guianensis, and is associated with the stimulation of the metabolic routes syntheses of proline and arginine.
The tolerant specie, S. macrocephala, mainly incorporates ammonium into glutamine, preventing the accumulation of arginine.

The aluminum exerts a beneficial effect, partially alleviating the ammonium toxicity in S. guianensis, increasing the asparagine retention and reducing the arginine composition in the root system.

In the presence of the nitric source, the aluminum influences the interconvertion of $\mathrm{N}$-aminic in the two species, however the percentage composition of $\mathrm{N}$-amino acids was more altered in the $S$. macrocephala.

In the presence of the nitric source, the aluminum increases the potassium concentrations only in the tolerant specie, the $S$. macrocephala.

\section{Literature Cited}

Amaral, J.A.T. do; Cordeiro, A.T.; Rena, A.B.

2000. Efeitos do alumínio, nitrato e amônio sobre a composição de metabólitos nitrogenados e de carboidratos em Stylosanthes guianensis e S. macrocephala. Pesquisa Agropecuária Brasileira, 35 (2): 313-320.

Amaral, J.A.T. do; Amaral, J.F.T. do; Schmildt, E.R.; Coelho, R.I. 2009. Métodos de análise quantitativa do crescimento de plantas. In: Ferreira et al. (Eds). Tópicos especiais em produção vegetal I. CCA-UFES, Alegre, pp. 259-276.

Atkins, C.; Beevers, L.

1990. Synthesis, transport and utilization of translocated soluts of nitrogen. In: Abrol, Y.P. (Ed.). Nitrogen in higher plants. Research Studies, Taunton, pp. 223-295.

Basso, L.H.M.; Lima, G.P.P.; Gonçalves, A.N.; Vilhena, S.M.C.; Padilha, C. do C.F.

2007. Efeito do alumínio no conteúdo de poliaminas livres e atividade da fosfatase ácida durante o crescimento de brotações de Eucalyptus grandis x E. urophylla cultivadas in vitro. Sciencia Forestalis, 75: 9-18.

Basu, U.; Good, A.G.; Aung, T.; Slaski, J. Basu, A.; Briggs, K.G.; Taylor, G.J.

1999. A 23-KDa root exudates polypeptide co-segregates with aluminum resistance in Triticum aestivum. Physiologia Plantarum, 106 (1): 53-61.

Bryan, J.K.

1976. Amino acid biosynthesis and its regulation. In: Bonner, J.; Varner, J. E. (Eds.). Plant biochemistry, 3. ed. Academic Press, New York, pp. 525-560.

Cordeiro, A.T.

1981. Efeito de níveis de nitrato, amônio e alumínio sobre o crescimento e sobre a absorção de fósforo e de nitrogênio em Stylosanthes guianensis e Stylosanthes macrocephala. Viçosa: 1981. 53 f. Dissertação (Mestrado em Fisiologia Vegetal) - Universidade Federal de Viçosa.

Delhaize, E.; Ryan, P.R.

1995. Aluminum toxicity and tolerance in plants. Plant Physiology, 107 (2): 315-321.

Fawzy, H.; Overstreet, R.; Jacobson, L.

1954. The influence of hydrogen ion concentration on cation absorption by barley roots. Plant Physiology, 29: 234-237.
Foy, C.D.; Chaney, R.L.; White, M.C.

1978. The physiology of metal toxicity in plants. Annual Review Plant Physiology, 29: 511-566.

Gonçalves, M.C.

1983. Influência do alumínio, nitrato e amônio na absorção e na assimilação do nitrogênio, em Stylosanthes guianensis e S. macrocephala. Viçosa: 1983. 38 f. Dissertação (Mestrado em Fisiologia Vegetal) - Universidade Federal de Viçosa.

Hageman, R.H.; Below, F.E.

1990. Role of nitrogen metabolism in crop productivity. In: Abrol, Y.P. (Ed.). Nitrogen in higher plants. Research Studies, Taunton, pp. 313-334.

Iuchi, S.; Koyama, H.; Iuchi, A.; Kobayashi, Y.; Kitabayashi, S.; Kobayashi, Y.; Ikka, T., Hirayama, T.; Shinozaki, K.; Kobayashi, M.

2007. Zinc finger protein STOP1 is critical for proton tolerance in Arabidopsis and coregulates a key gene in aluminum tolerance. Proceedings of the National Academy of Sciences of the United States of America, 104 (23): 9900-9905.

Jones, D.L.

1998 Organic acids in the rhizosphere: a critical review. Plant and Soil, 205 (1): 25-44.

Kirkby, E.A.; Knight, A.H.

1977 Influence of the level of nitrate nutrition on ion uptake and assimilation, organic acid accumulation, and cationanion balance in whole tomato plants. Plant Physiology, 60: 349-353.

Klimashevskii, É.L.; Markova, YO, A.; Seregina, M.L.; Grodzinskii, D.M.; Kozarenko, T.D.

1970 Specifics of the physiological activity of pea plants in connection with unequal resistance of different varieties to mobile aluminum. Soviet Plant Physiology, 17 (3): 372-378.

Kobayashi, Y.; Hoekenga, O.A.; Itoh, H.; Nakashima, M.; Saito, S.; Shaff, J.E.; Maron, L.G.; Pineros, M.A.; Kochian, L.V.; Koyama, H.

2007. Characterization of AtALMT1 expression in aluminuminducible malate release and its role for rhizotoxic stress tolerance in Arabidopsis. Plant Physiology, 145 (3): 843-852. 
Kochian, L.V.

1995. Cellular Mechanisms of aluminum toxity and resistance in plants. Annual Review Plant Physiology and Plant Molecular Biology, 46: 237-260.

Kochian, L.V.; Hoekenga, O.A.; Piñeros, M.A.

2004. How do crop plants tolerate acid soils? Mechanisms of aluminum tolerance and phosphorous efficiency. Annual Review of Plant Biology, 55: 459-493.

Kotze, W.A.G.; Shear, C.B.; Faust, M.

1977. Effect of nitrogen source and aluminum in nutrient solution on the growth and mineral nutrition of apple and peach seedlings. Journal American Society and Horticultural Science, 102 (3): 279-282.

Kumar, P.A.; Abrol, Y.P.

1990. Ammonia assimilation in higher plants. In: Abrol, Y. P. (Ed.). Nitrogen in higher plants. Research Studies, Taunton, pp. 159-179.

Lea, P.J.; Miflin, B.J.

2003 Review: glutamate synthase and the synthesis of glutamate in plants. Plant Physiology and Biochemistry, 41 (6-7): 555-564.

Li, X.F.; Ma, J.F.; Matsumoto, H.

2000. Pattern of aluminum-induced secretion of organic acids differs between rye and wheat. Plant Physiology, 123: 1537-1544.

Ma, J.F.; Zheng, J.; Matsumoto, H.

1997. Specific secretion of citric acid induced by Al stress in Cassia tora L. Plant and cell Physiology, 38 (9): 1019-1025.

Machado, M.A.; Rena, A.B.; Santanna, R.; Estevão, M.;

Caldas, L.S.

1992. Kinetic of phosphate absorption by Stylosanthes guianensis and S. macrocephala in presence of aluminium. Journal of Plant Nutrition, 15 (12): 2777-2788.

Malavolta, E.; Vitti, G.C.; Oliveira, S.A.

1997. Avaliação do estado nutricional das plantas: princípios e aplicações. 2.ed. Potafos, Piracicaba, 319 p.

Marschner, $\mathrm{H}$.

1995. Mineral nutrition of higher plants. Academic Press, London, $674 \mathrm{p}$.

Maynard, D.N.; Barker, A.V.

1969. Studies on the tolerance of plants to ammonium nutrition. Journal American Society and Horticultural Science, 94 (3): 235-239.
Miyasaka, S.C.; Buta, J.G.; Howell, R.K.; Foy, C.D. 1991. Mechanism of aluminum tolerance in snapbeans: Root Exudation of Citric Acid. Plant Physiology, 96 (3): 737-743.

Mosquim, P.R.

1978. Influência do alumínio sobre o crescimento e o metabolismo em plantas de Stylosanthes humilis H.B.K. Viçosa: 1978. 29 f. Dissertação (Mestrado em Fisiologia Vegetal) - Universidade Federal de Viçosa.

Pellet, D.M.; Grunes, D.L.; Kochian, L.V.

1995. Organic acid exudation as an aluminum-tolerance mechanism in maize (Zea mays L.). Planta, 196 (4): 788-795.

Roberts, D.R.; Walker, M.A.; Thompson, J.E.; Dumbroff, E.B. 1983 The effects on inhibition of polyamine and ethylene biosynthesis on senescence, thylene producion and polyamine levels in cut carnations. Plant Cell Physiology, 25: 315-322.

Ryan, P.R.; Sherrett, M. Findlay, G.P.; Delhaize, E.; Tyerman, S.D. 1997. Aluminum activates an anion channel in the apical cells of wheat roots. Proceedings National Academic Science, 94: 6547-6552.

Samac, D. A.; Tesfaye, M.

2003. Plant improvement for tolerance to aluminum in acid soils - a review. Plant Cell, Tissue and Organ Culture, 75 (3): 189-207.

Shen, H.; Yan, X.; Cai, K.; Matsumoto, H.

2004. Differential Al resístance and citrate secretion in the tap and basal roots of common bean seedlings. Physiologia Plantarum, 121 (4): 595-603.

Spackman, D.H.; Stein, W.H.; Moore, S.

1958. Automatic recording apparatus for use in the chromatography of amino acids. Analytical Chemistry, 30 (7): 1190-1206.

Taiz, L.; Zeiger, E.

2009 Fisiologia vegetal. 4. ed. Artmed, Porto Alegre, 819 p.

Yang, J.L.; Zhang, L.; Li, Y. .; You, J.F.; Wu, P.; Zheng, S.J.

2006. Citrate transporters play a critical role in aluminiumstimulated citrate efflux in rice bean (Vigna umbellate) roots. Annals of Botany, 97 (4): 579-584.

Yang, Z.M.; Nian, H.; Sivaguru, M.; Tanakamaru, S.; Matsumoto, H. 2001. Characterization of aluminium-induced citrate secretion in aluminium-tolerant soybean (Glycine max). Physiologia Plantarum, 113 (1): 64-71. 